\title{
Efektivitas Model PLGI untuk Meningkatkan Penguasaan Konsep Siswa pada Materi Garam Menghidrolisis
}

\author{
Angela Merichi Ayu P.*, Nina Kadaritna, Lisa Tania \\ FKIP Universitas Lampung J1. Prof. Dr Soemantri Brojonegoro No. 1 Bandar Lampung \\ *e-mail: angelamerichiayu240897@gmail.com, Telp: +6288268227233
}

\begin{abstract}
Abtract: The Effectiveness of the PLGI Model to Improve Student's Concepts Mastery on Hydrolyzing Salt Topic. This study was aimed to describe the effectiveness of the PLGI model to improve concepts mastery of students on hydrolyzing salt topics. The method in this study was quasi-experiment, a purposive sampling technique was used in determining the samples thus XI MIPA 1 was chosen as an experiment class and XI MIPA 2 was a control class. The data analysis technique uses the non-parametric statistical test, the Mann-Whitney $U$ test. Based on the results of statistical calculation that the average concepts mastery $n$-gain of the experimental class was 0,76 and the average $n$ gain control class was moderate, 0,47. The Mann-Whitney $U$ test result showed a significant difference between the average n-gain in the experimental class and the control class with a significant value of 0,000. Based on the results of these studies it can be concluded that the PLGI model is effective to improve concepts mastery of hydrolyzing salt topic.
\end{abstract}

Keywords: hydrolyzing salt, PLGI model, concepts mastery

Penelitian ini bertujuan mendeskripsikan efektivitas model PLGI untuk meningkatkan penguasaan konsep oleh siswa pada materi garam menghidrolisis. Desain dalam penelitian ini adalah quasi experiment, pengambilan sampel dipilih dengan teknik purposive sampling, didapatkan kelas XI MIPA 1 sebagai kelas eksperimen dan XI MIPA 2 sebagai kelas kontrol. Teknik analisis data menggunakan uji statistik non parametrik yaitu uji Mann-Whitney U. Berdasarkan hasil dari perhitungan statistik rata-rata n-gain penguasaan konsep kelas eksperimen berkriteria tinggi yaitu 0,76 dan rata-rata n-gain kelas kontrol berkriteria sedang yaitu 0,47 . Hasil uji Mann-Whitney U menunjukkan perbedaan yang signifikan antara rata-rata n-gain pada kelas eksperimen dengan kelas kontrol dengan nilai signifikannya 0,000 . Berdasarkan hasil penelitian tersebut dapat disimpulkan bahwa model PLGI efektif untuk meningkatkan penguasaan konsep pada materi garam menghidrolisis.

Kata kunci: garam menghidrolisis, model PLGI, penguasaan konsep 


\section{PENDAHULUAN}

Pendidikan merupakan aspek penting dalam mencerdaskan kehidupan bangsa. Peningkatan mutu pendidikan tidak dapat terlepas dari berbagai upaya. Salah satunya upaya yang dilakukan pemerintah adalah menerapkan dan mengembangkan kurikulum berbasis kompetensi pada tahun 2004 dan 2006 hingga kurikulum 2013. Kurikulum 2013 ditetapkan sebagai upaya meningkatkan kualitas pendidikan Indonesia diseluruh jenjang yang dinilai dari tiga ranah kompetensi, yaitu: pengetahuan, sikap, dan keterampilan. Tahap pelaksanaan kurikulum 2013 berfokus pada kegiatan aktif siswa melalui suatu proses ilmiah dengan tujuan agar pembelajaran tidak hanya menciptakan peserta didik yang mempunyai kompetensi pengetahuan saja, tetapi juga mampu menciptakan peserta didik yang baik dalam sikap dan keterampilan (Wasonowati, Redjeki, dan Ariani, 2014).

Kimia merupakan salah satu mata pelajaran sains yang dianggap sulit oleh siswa, karena materi pelajaran kimia berisi konsep-konsep yang cukup sulit untuk dipahami karena menyangkut reaksi-reaksi kimia dan perhitungan serta menyangkut konsep-konsep yang bersifat abstrak (Wang, 2007; Sunyono, 2009). Menurut Wiseman, 2002 menyatakan bahwa kebanyakan siswa mengalami kesulitan dalam mempelajari konsep kimia dari pada konsep pelajaran yang lain, hal ini dikarenakan karakteristik dari ilmu kimia yang sifatnya abstrak. Kemampuan siswa dalam memahami konsep kimia sudah pasti memengaruhi kemampuan siswa dalam menyelesaikan soal kimia sehingga dapat dipastikan berdampak pada hasil belajar kimia (Rusmansyah, 2002).

Menurut Moseley, (2005) dalam mempelajari ilmu kimia, pengetahuan bukanlah tujuan utama, melainkan hanya sebagai wadah untuk mengembangkan sikap dan keterampilan-keterampilan tertentu. Sikap dan keterampilan tersebut yang nantinya akan berguna dalam menjalani kehidupan bermasyarakat. Dengan demikian, ilmu kimia pada hakikatnya bukan hanya berupa produk pengetahuan, melainkan juga berupa proses termasuk keterampilan, serta sikap ilmiah. Selama proses pembelajaran keterampilan berpikir perlu dilatih dan dikembangkan mengingat keterampilan berpikir merupakan modal dasar dalam menghadapai tantangan dunia kerja dan lingkungan masyarakat (Fadiawati, 2016).

Berdasarkan hasil observasi dan wawancara yang telah dilakukan dengan guru mata pelajaran kimia kelas XI di salah satu SMA di Bandar Lampung, guru menyatakan bahwa hasil pencapaian siswa pada materi garam menghidrolisis mencapai $65 \%$ dengan KKM (Kriteria Ketuntasan Minimum) sebesar 78. Hal ini masih jauh dengan keinginan guru yaitu minimal $85 \%$. Hal tersebut dikarenakan dari pembelajaran kimia yang masih terpusat kepada guru dengan menggunakan metode ceramah, sesekali berdiskusi, dan latihan soal. Dengan penerapan pembelajaran yang seperti itu, maka siswa kurang dilibatkan secara aktif dalam pembelajaran, sehingga tidak terjadi peningkatan penguasaan konsep siswa.

Penguasaan konsep merupakan suatu kemampuan menangkap pengertian-pengertian seperti mampu mengungkapkan suatu materi yang 
disajikan kedalam bentuk yang lebih dipahami, mampu memberikan interpretasi dan mengaplikasikannya.

Siswa yang mampu menguasai konsep dengan baik akan dapat menyelesaikan masalah terkait dengan materi tersebut sehingga dapat meningkatkan hasil belajar siswa. Hal ini sesuai dengan hasil penelitian Widyowati (2014) yang menyatakan bahwa kemampuan siswa dalam memahami konsep kimia memiliki hubungan positif dan signifikan terhadap hasil belajar siswa, artinya semakin tinggi penguasaan konsep kimia siswa maka semakin tinggi pula hasil belajar kimia siswa (Suyanti, 2016).

Salah satu model pembelajaran yang diharapkan dapat mengasah penguasaan konsep siswa adalah penggunaan model pembelajaran PLGI dalam salah satu kompetensi dasar pada materi kimia yaitu menganalisis kesetimbangan ion dalam larutan garam dan menghubungkan pHnya. Peer-Led Guided Inquiry (PLGI) yaitu model pembelajaran yang membangun interaksi aktif antara siswa dalam sebuah kelompok dengan tutor sebaya yang membantu guru untuk menyampaikan materi kepada anggota masing-masing kelompok. Dalam pembelajaran ini siswa cukup berperan besar atau berperan aktif karena pembelajaran berpusat pada siswa dan tidak lagi terpusat pada guru (Nahdiah, Mahdian, dan Hamid, 2017).

Hasil observasi awal yang telah dilakukan dengan cara wawancara dengan guru bidang studi kimia di salah satu SMA di Bandar Lampung, diperoleh bahwa sebagian besar siswa masih kesulitan untuk memahami materi yang telah diberikan guru. Permasalahan lainnya ialah siswa belum terbiasa untuk berpikir tingkat tinggi dalam pembelajaran dan siswa juga jarang dilatih untuk mengaitkan materi yang sudah dipelajari sebelumnya dengan fenomena nyata atau fenomena dalam kehidupan sehari-hari, sehingga penguasaan konsep siswa sangat kurang. Berdasarkan uraian di atas, maka peneliti terdorong untuk melakukan penelitian dengan judul "Efektivitas Model PLGI Untuk Meningkatkan Penguasaan Konsep Siswa Pada Materi Garam Menghidrolisis"

\section{METODE}

\section{Pelaksanaan Penelitian}

Penelitian ini dilakukan di salah satu SMA di Bandar Lampung. Populasi pada penelitian ini yaitu seluruh siswa kelas XI tahun ajaran 2018/2019, dan sampel dari penelitian ini adalah kelas XI IPA 1 sebagai kelas eksperimen dan kelas XI IPA 2 sebagai kelas kontrol yang diambil dengan menggunakan teknik purposive sampling

Variabel dalam penelitian ini terdiri dari variabel bebas, variabel terikat dan variabel kontrol. Variabel bebasnya yaitu pembelajaran model PLGI (pada kelas eksperimen) dan model konvensional (pada kelas kontrol). Variabel terikatnya yaitu penguasaan konsep siswa dan variabel kontrol dalam penelitian ini yaitu materi garam menghidrolisis.

Metode yang digunakan dalam penelitian ini adalah quasi experiment dengan desain pretes-postes control group design yang dilakukan terhadap dua kelas penelitian. Kelas eksperimen menggunakan model pembelajaran PLGI pada kelas XI MIPA 1, sedangkan kelas kontrol menggunakan model pembelajaran konvensional pada kelas XI MIPA 2. 
Tabel 1. Desain penelitian pretespostes control group design

\begin{tabular}{llll}
\hline $\begin{array}{l}\text { Kelas } \\
\text { penelitian }\end{array}$ & Pretes & $\begin{array}{l}\text { Perlaku } \\
\text { an }\end{array}$ & Postes \\
\hline Eksperim & $\mathrm{T}_{0}$ & $\mathrm{X}$ & $\mathrm{T}_{1}$ \\
en & $\mathrm{T}_{0}$ & $\mathrm{Y}$ & $\mathrm{T}_{1}$ \\
Kontrol & & & \\
\hline
\end{tabular}

$\mathrm{T}_{0}$ ialah retes kelas eksperimen dan kelas kontrol, $\mathrm{X}$ ialah model pembelajaran PLGI, Y ialah model pembelajaran konvensional, dan $\mathrm{T}_{1}$ ialah postes kelas eksperimen dan kelas kontrol

Penelitian ini terdapat tahap prapenelitian yaitu meminta izin penelitian kepada kepala sekolah SMA, tahap penelitian yaitu melakukan kegiatan pembelajaran di kelas eksperimen dan di kelas kontrol dan tahap pascapenelitian yaitu menganalisis data, pembahasan dan menarik kesimpulan.

\section{Analisis Data}

Data-data yang terkumpul dari hasil penelitian selanjutnya diolah dengan menggunakan Microsoft Office Excel dan SPSS versi 23.0. Adapun langkah-langkah dalam mengolah data yaitu menghitung nilai pretes dan postes

Nilai siswa $=\frac{\text { jumlah skor yang diperoleh }}{\text { jumlah skor maksimal }} \times 100$

Rata-rata nilai siswa $=\frac{\text { jumlah nilai siswa }}{\text { jumlah seluruh siswa }}$

Kemudian menghitung $n$-gain

$n$-gain siswa $=\frac{\text { nilai postes-nilai pretes }}{100 \text {-nilai pretes }}$

Rata-rata $n$-gain $=\frac{\text { jumlah } n \text {-gain seluruh siswa }}{\text { jumlah siswa }}$

Setelah menghitung nilai siswa dan $n$-gain, kemudian melakukan uji kesamaan dua rata-rata dan perbedaan dua rata-rata. Jika kedua sampel tidak berdistribusi normal dan homogen, maka pengujian kesamaan dua ratarata menggunakan uji statistik non parametrik yaitu uji Mann-Whitney $U$.

Dasar pengambilan keputusan berdasarkan probabilitas. Jika probabilitas $>0,05$, maka $\mathrm{H}_{0}$ diterima. Jika probabilitas $<0,05$, maka $\mathrm{H}_{1}$ diterima.

Pada uji perbedaaan dua rata-rata, kedua sampel tidak berdistribusi normal dan homogen, maka pengujian kesamaan dua rata-rata tidak menggunakan uji statistik parametrik, melainkan menggunakan uji statistik non parametrik yaitu uji Mann-Whitney $U$. Dasar pengambilan keputusan berdasarkan probabilitas. Jika probabilitas $>0,05$, maka $\mathrm{H}_{0}$ diterima. Jika probabilitas $<0,05$, maka $\mathrm{H}_{1}$ diterima.

Setelah itu menghitung data pendukung yaitu berupa data aktivitas siswa dan data keterlaksanaan model PLGI dengan cara menghitung jumlah skor yang diberikan oleh observer untuk setiap aspek pengamatan, kemudian menghitung persentase dengan rumus:

$$
\% \mathrm{Ji}=\frac{\sum \mathrm{Ji}}{\mathrm{N}} \times 100 \%
$$

$\% \mathrm{Ji}$ ialah Persentase dari skor ideal untuk setiap aspek pengamatan pada pertemuan ke-i, $\sum \mathrm{Ji}$ ialah Jumlah skor setiap aspek pengamatan yang diberikan oleh observer pada pertemuan ke-i dan $\mathrm{N}$ ialah skor maksimal (skor ideal).

\section{HASIL DAN PEMBAHASAN}

Berdasarkan penelitian yang telah dilakukan di salah satu SMA di Bandar Lampung di kelas XI IPA 1 sebagai kelas eksperimen dan kelas XI IPA 2 sebagai kelas kontrol, diperoleh data berupa nilai pretes dan nilai postes penguasaan konsep siswa. Data tersebut selanjutnya diolah menggunakan Microsoft Office Excel dan SPSS versi23.0. 
Setelah dilakukan pretes dan postes, maka diperoleh data berupa nilai pretes dan postes penguasaan konsep. Nilai rata-rata pretes dan postes penguasaan konsep siswa disajikan dalam Gambar 1.

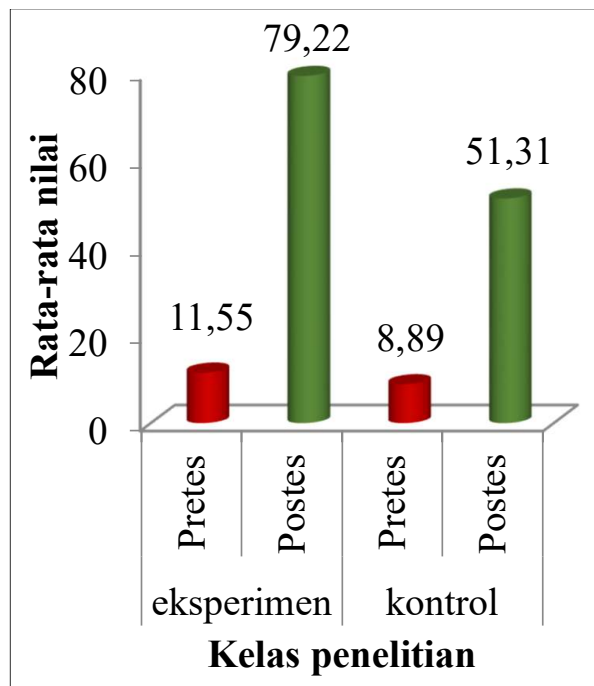

Gambar 1. Rata-rata nilai pretes dan rata-rata nilai postes penguasaan konsep siswa

Pada Gambar 2 terlihat bahwa penguasaan awal konsep siswa pada kelas eksperimen maupun kelas kontrol tidak jauh berbeda. Hasil postes penguasaan konsep pada kelas eksperimen mengalami peningkatan begitupun pada kelas kontrol tetapi jika dibandingkan nilai rata-rata postes kelas eksperimen jauh lebih besar dibandingkan dengan kelas kontrol. Berdasarkan data tersebut menunjukan bahwa peningkatan penguasaan konsep pada kelas eksperimen lebih besar dibandingkan dengan peningkatan penguasaan konsep pada kelas kontrol.

Kemudian menghitung n-gain yang didapat dari perhitungan ratarata nilai pretes dan rata-rata nilai postes pada materi garam menghidrolisis siswa di kelas eksperimen maupun kelas kontrol.
Adapun rata-rata n-gain siswa disajikan pada Gambar 2.

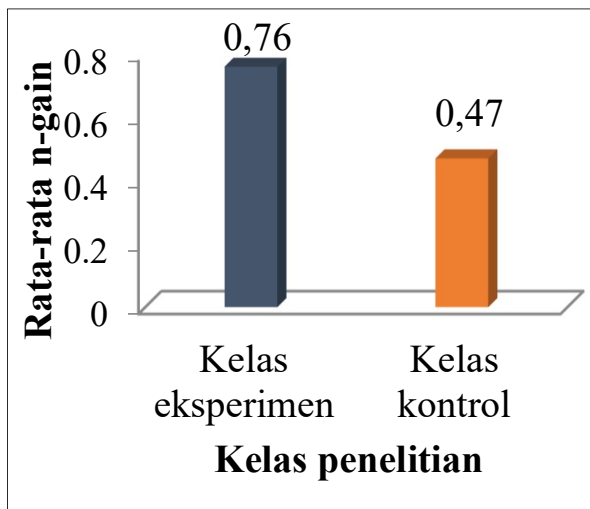

Gambar 2. Rata-rata $n$-gain penguasaan konsep siswa

Berdasarkan Gambar 3 terlihat bahwa nilai rata-rata n-gain penguasaan konsep siswa pada kelas eksperimen berkategori tinggi sedangkan pada kelas kontrol berkategori sedang. Berdasarkan data tersebut dapat terlihat bahwa rata-rata $n$-gain pada kelas eksperimen lebih tinggi daripada rata-rata nilai $n$-gain pada kelas kontrol. Berdasarkan data tersebut, maka dapat dilihat bahwa model pembelajaran PLGI dapat meningkatkan penguasaan konsep siswa.

Sebelum dilakukan uji kesamaan dua rata-rata dilakukan terlebuh dahulu uji prasyarat analisis yaitu uji normalitas dan uji homogenitas terhadap nilai pretes.

Tabel 2. Hasil uji normalitas penguasan konsep

\begin{tabular}{lll}
\hline $\begin{array}{l}\text { Kelas } \\
\text { Penelitian }\end{array}$ & \multicolumn{2}{c}{ Uji Normalitas } \\
\cline { 2 - 3 } & Nilai sig. & $\begin{array}{l}\text { Kriteria } \\
\text { Uji }\end{array}$ \\
\hline Kontrol & 0,000 & $\begin{array}{l}\text { Terima } \mathrm{H}_{1} \\
\text { jika nilai } \\
\text { sig }<0,005\end{array}$ \\
\hline Eksperimen & 0,012 &
\end{tabular}

Berdasarkan tabel di atas terlihat bahwa hasil uji normalitas pretes penguasaan konsep di kelas 
eksperimen maupun di kelas kontrol nilai signifikannya kurang dari 0,05 . Hal ini menunjukkan bahwa terima $\mathrm{H}_{1}$ yang berarti bahwa nilai pretes penguasaan konsep berasal dari populasi yang berdistribusi tidak normal.

Berdasarkan hasil uji homogenitas pretes penguasaan konsep di kelas eksperimen maupun di kelas kontrol didapatkan nilai signifikannya sebesar 0,645 yang artinya lebih dari 0,05 . $\mathrm{Hal}$ ini menunjukkan terima $\mathrm{H}_{0}$ yang berarti bahwa nilai pretes penguasaan konsep berasal dari populasi yang memiliki varians yang homogen.

Setelah diuji normalitas dan homogenitas selanjutnya melakukan uji kesamaan dua rata rata. Dari uji normalitas dan homogenitas ternyata kedua sampel tidak berdistribusi normal tetapi homogen, sehingga uji kesamaan dua rata-rata menggunakan uji statistik non parametrik. yaitu uji Mann-Whitney U. Berdasarkan hasil output SPSS 23.0 menunjukkan bahwa nilai Sig (2-tailed) sebesar 0,226 artinya $>0,05$. Hal ini menunjukkan bahwa terima $\mathrm{H}_{0}$ yang berarti bahwa nilai rata-rata nilai penguasaan konsep siswa pada kelas eksperimen tidak jauh berbeda pada kelas kontrol.

Sebelum dilakukan uji kesamaan dua rata-rata dilakukan terlebih dahulu uji prasyarat analisis yaitu uji normalitas dan uji homogenitas ratarata $n$-gain. Berikut uji normaslitas $n$ gain penguasaan konsep siswa:

Tabel 3. Hasil uji normalitas n-gain penguasan konsep

\begin{tabular}{lll}
\hline \multirow{2}{*}{$\begin{array}{l}\text { Kelas } \\
\text { Penelitian }\end{array}$} & \multicolumn{2}{l}{ Uji Normalitas } \\
\cline { 2 - 2 } & $\begin{array}{l}\text { Nilai } \\
\text { sig. }\end{array}$ & Kriteria Uji \\
\hline Kontrol & 0,026 & $\begin{array}{l}\text { Terima } \mathrm{H}_{1} \\
\text { jika nilai } \\
\text { sig }<0,005\end{array}$ \\
\hline Eksperimen & 0,000 & \\
\hline
\end{tabular}

Berdasarkan Tabel 3 terlihat bahwa hasil uji normalitas n-gain penguasaan konsep di kelas eksperimen maupun di kelas kontrol nilai signifikannya kurang dari 0,05 . Hal ini menunjukkan bahwa terima $\mathrm{H}_{1}$ yang berarti bahwa n-gain penguasaan konsep berasal dari populasi yang berdistribusi tidak normal.

Hasil uji homogenitas n-gain penguasaan konsep di kelas eksperimen maupun di kelas kontrol diperoleh nilai signifikannya 0,645 yang artinya lebih dari 0,05 . Hal ini menunjukkan bahwa terima $\mathrm{H}_{0}$ yang berarti bahwa n-gain penguasaan konsep berasal dari populasi yang memiliki varians yang homogen.

Setelah diuji normalitas dan homogenitas selanjutnya melakukan uji kesamaan dua rata rata. Dari uji normalitas dan homogenitas ternyata kedua sampel tidak berdistribusi normal tetapi homogen, sehingga uji kesamaan dua rata-rata ini menggunakan uji statistik non parametrik yaitu uji Mann-Whitney $U$.

Berdasarkan hasil output SPSS 23.0 menunjukkan bahwa nilai Sig (2tailed) sebesar 0,000 artinya $<0,05$ maka terima $\mathrm{H}_{1}$ yang berarti bahwa rata-rata nilai n-gain penguasaan konsep siswa di kelas eksperimen tidak sama dengan rata-rata $n$-gain penguasaan konsep siswa di kelas kontrol pada materi garam menghidrolisis.

Selama proses pembelajaran, dimulai dari pendahuluan sampai dengan kegiatan akhir/penutup, aktivitas siswa diamati oleh dua orang observer. Aktivitas siswa yang diamati sesuai dengan lembar keterlaksanaan aktivitas siswa. Aktivitas siswa yang terlihat berupa aktivitas 1 yaitu mengamati, aktivitas 2 yaitu bertanya, aktiitas 3 yaitu 
mengemukakan ide atau pendapat, dan aktivitas 4 yaitu kerjasama. Berikut aktivitas siswa diperoleh data yang disajikan pada Gambar 3.

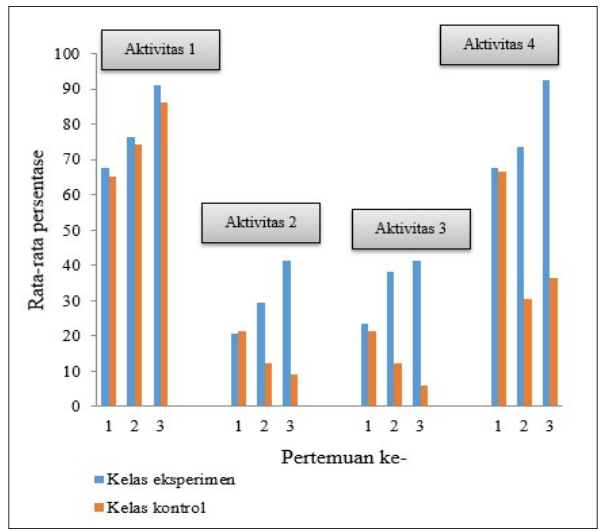

Gambar 3. Rata-rata persentase aktivitas siswa

Penelitian ini dilakukan menggunakan lembar keterlaksanaan model PLGI, lembar ini digunakan untuk mengukur seberapa besar guru sudah melaksanakan model PLGI. Seperti aktivitas siswa, kemampuan guru dalam melaksanakan model PLGI dinilai oleh dua orang observer dimulai dari pendahuluan sampai kegiatan penutup. Adapun presentase hasil keterlaksaan model PLGI disajikan pada Gambar 4.

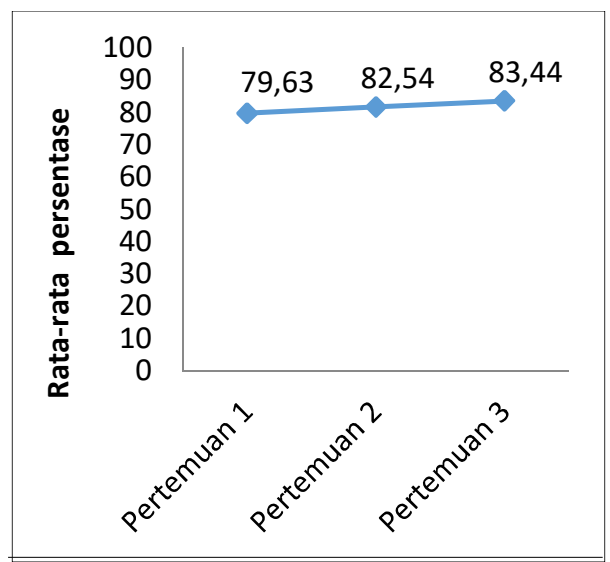

Gambar 4. Rata-rata persentase keterlaksanaan model PLGI
Pada Gambar 4 di atas terlihat bahwa persentase keterlaksaan model PLGI di kelas eksperimen mengalami peningkatan dari pertemuan pertama ke pertemuan ketiga, sehingga dapat dikatakan bahwa guru sudah melaksanakan model PLGI dengan baik dalam mengelola pembelajaran di kelas eksperimen

Penelitian dilakukan di salah satu SMA di Bandar Lampung. Penelitian dengan materi garam menghidrolisis ini dilaksanakan 3 kali pertemuan dimana 1 kali pertemuan terdiri dari 3 jam pelajaran dan setiap jam pelajaran adalah 45 menit, sehingga total jam pelajaran untuk materi garam menghidrolisis adalah $9 \times 45$ menit dengan pretes dan postes dilakukan di luar jam pelajaran. Pembagian kelompok dan penentuan tutor sebaya pada kelas eksperimen didasarkan pada pendapat guru, dimana didapatkan 5 kelompok dengan masing-masing anggota kelompok 7-8 siswa. Pertemuan pertama membahas mengenai sifat larutan garam, pertemuan kedua membahas mengenai konsep hidrolisis, dan pertemuan ketiga membahas mengenai penentuan $\mathrm{pH}$.

Setelah dilakukan penelitian maka mendapatkan data yang akan digunakan untuk diolah dan dianalisis bahwa model PLGI efektif terhadap penguasaan konsep siswa pada materi garam menghidrolisis. Berdasarkan analisis data hasil penelitian menunjukkan bahwa pembelajaran menggunakan model PLGI meningkatkan penguasaan konsep siswa. Rata-rata nilai n-gain penguasaan konsep siswa di kelas eksperimen lebih tinggi daripada ratarata nilai $n$-gain penguasaan konsep siswa di kelas kontrol. Hal ini dapat dikatakan bahwa model PLGI efektif untuk meningkatkan penguasaan 
konsep siswa pada materi garam menghidrolisis.

Untuk mengetahui mengapa hal tersebut dapat terjadi, dijelaskan melalui proses pembelajaran dengan menggunakan LKS PLGI. Berikut merupakan penjabaran tahapan PLGI yang dilakukan selama penelitian yang dilakukan pada kelas eksperimen

Pada pertemuan pertama di kelas eksperimen maupun kelas kontrol dilakukan pretes yang keduanya dilakukan di luar jam pelajaran. Pada kelas kontrol maupun eksperimen melakukan percobaan di laboratorium perbedaannya pada kelas eksperimen diberikan LKS 1 sebagai acuan pembelajaran sedangkan pada kelas kontrol hanya diberikan tabel hasil pengamatannya saja. Kemudian mengisi nama kelompok siswa, membaca petunjuk pengisian LKS, guru memberitahukan atau membaca KD maupun indikator yang harus dicapai siswa. Kemudian memulai pembelajaran.

Tahapan dalam LKS model PLGI yang pertama yaitu orientasi masalah. Pada LKS telah diberikan suatu wacana dan grafik kurva titrasi yang berasal dari asam kuat basa kuat, asam kuat basa lemah, dan asam lemah basa kuat. Pembacaan wacana maupun pengamatan grafik dilakukan perkelompok yang telah dibentuk oleh guru mata pelajaran. Selanjutnya tutor sebaya memimpin siswa menuliskan rumusan masalah atau suatu permasalahan berdasarkan wacana maupun kurva tersebut pada LKS. Pada tahap ini tutor sebaya maupun teman sekelompok mengamati dengan seksama wacana yang ada di LKS dan juga kerjasama dengan masing-masing anggota kelompok untuk membuat rumusan masalah. Aktivitas siswa yang terlihat lainnya yaitu bertanya sejumlah 1 siswa yaitu mengenai cara membuat rumusan masalah dan mengemukakan pendapat sebanyak 2 siswa. Berikut beberapa rumusan masalah yang telah dituliskan siswa dan tutor sebaya ialah apa saja sifat garam?, apa ada hubungan sifat larutan garam dengn $\mathrm{pH}$ ?, dan bagaimana hubungan titik ekuivalen titrasi asam basa dengan sifat larutan garam.

Rumusan masalah yang dibuat oleh siswa kurang sesuai dengan yang guru inginkan. Rumusan masalah yang guru inginkan adalah mengapa garam dapat bersifat asam, basa dan netral? dari komponen apa saja garam yang bersifat asam, basa, dan netral?. Pada tahap ini aktivitas siswa yang dilatihkan ialah mengemukakan ide atau pendapat.

Kemudian guru meminta siswa dan tutor sebaya untuk memperhatikan tahap selanjutnya yaitu membuat hipotesis. Pada tahap ini banyak siswa yang melakukan aktivitas berupa mengamati dan kerjasama dalam membuat hipotesis. Kemudian untuk aktivitas siswa yang berupa mengemukakan pendapat terdapat 2 siswa dan bertanya terdapat 1 siswa. Berikut merupakan beberapa hipotesis yang telah dibuat oleh siswa ialah garam dapat bersifat asam, basa, dan netral. Hipotesis yang dibuat oleh siswa belum sesuai yang guru inginkan. Hipotesis yang guru inginkan adalah garam dapat bersifat asam basa dan netral berdasarkan kompenan asam basa penyusunnya.

Kemudian untuk mengetahui apakah hipotesis yang dibuat sesuai dengan teori yang akan dipelajari siswa dan tutor sebaya melakukan percobaan (pengumpulan data) mengenai sifat larutan garam dengan bahan-bahan yang digunakan adalah $\mathrm{NaCl}, \mathrm{KCl}, \quad \mathrm{NH}_{4} \mathrm{Cl}, \quad\left(\mathrm{NH}_{4}\right)_{2} \mathrm{SO}_{4}$, 
$\mathrm{CH}_{3} \mathrm{COONa}$, dan $\mathrm{Na}_{2} \mathrm{CO}_{3}$. Guru memberi arahan untuk melakukan praktikum dengan meminta salah satu siswa untuk membacakan langkah percobaan dan memberi arahan tempat pengambilan bahan, maupun cara membaca $\mathrm{pH}$ universal perkelompok yang sudah mengambil bahan. Setelah siswa dan tutor sebaya telah selesai melakukan percobaannya maka guru menunjuk perwakilan kelompok untuk membacakan hasil dari pengukuran $\mathrm{pH}$ masing-masing larutan. Pada tahap ini terdapat 3 siswa yang bertanya dan 2 siswa yang mengemukakan pendapatnya, sedangkan hamper seluruh siswa yang mengamati dan bekerjasama.

Sebelum menemukan suatu konsep yang berkaitan dengan materi sebelumnya siswa dan tutor sebaya harus menganalisis data yang telah didapat dengan mengerjakan pertanyaan-pertanyaan yang ada pada LKS 1. Guru memberikan waktu untuk mengerjakan pertanyaanpertanyaan tersebut. Pada tahap ini peran tutor sebaya sangat penting dalam memberikan penjelasan kepada anggota kelompoknya. Dengan arahan dari pertanyaan LKS siswa dipastikan dapat membangun konsep mengenai sifat larutan garam baik melalui asam basa penyusunnya maupun berdasarkan nilai $\mathrm{Ka}$ dan Kbnya. Pada tahap mengumpulkan data dan menganalisis data aktivitas siswa yang terlihat yaitu bertanya sebanyak 3 siswa dan mengemukakan pendapat terlihat 1 siswa, sedangkan untuk mengamati dan kerjasama terlihat banyak dilakukan oleh siswa.

Setelah siswa dapat menemukan konsep materi yang telah mereka pelajari, maka siswa dapat menyimpulkan konsep materi yang mereka telah pelajari. Siswa menuliskan kesimpulan kelompoknya pada LKS 1 bagian membuat kesimpulan, selanjutnya guru akan menunjuk salah satu anak secara acak untuk menyimpulkan konsep materi yang telah mereka dapatkan (kecuali tutor sebaya).

Pada pertemuan pertama terlihat antusias yang diberikan pada kelas eksperimen selama proses pembelajaran tetapi masih banyak kesalahan pada hasil LKS karena model PLGI masih baru diimplementasikan. Hal ini didukung dari persentase aktivitas siswa sebesar 44,85 yang berkriteria sedang dan juga pelaksanaan model PLGI yang diimplementasikan guru dengan persentase sebesar 79,63 yang berkriteria tinggi. Guru sudah membimbing siswa dalam mengorientasi masalah di LKS, membuat hipotesis berdasarkan rumusan masalah yang telah dibuat siswa, mengumpulkan data berdasarkan percobaan yang telah dilakukan di dalam laboratorium mengenai identifikasi larutan garam, menganalisis data berdasarkan data yang diperoleh dari percobaan dan membuat kesimpulan berdasarkan pembelajaran yang telah dilakukan. Terjadi peningkatan dari pertemuan pertama sampai pertemuan kedua.

Pada kelas kontrol dilakukan praktikum yang sama dengan kelas eksperimen tetapi pada proses pembelajaran menggunakan model konvensional dimana guru hanya menerangkan materi yang dipelajari di papan tulis dan siswa hanya mendengarkan serta mencatat pelajaran. Hasil dari rata-rata aktivitas siswa pada pertemuan pertama pada bagian mengamati sebesar 21,5, bertanya sebesar 7 siswa, mengungkapkan ide/pendapat sebesar 7 siswa dan kerjasama sebesar 22 siswa. 
Pada pertemuan minggu kedua tahapan pembelajaran PLGI sama dengan pada pertemuan minggu pertama, hanya berbeda pada materi yang akan dicapai yaitu konsep hidrolisis. Tahapan dalam LKS model PLGI yang pertama yaitu orientasi masalah. Sebelumnya pada LKS telah diberikan suatu wacana dimana di dalam wacana tersebut terdapat reaksi asam basa Bronsted-Lowry yang telah mereka pelajari sebelumnya. Pembacaan wacana dilakukan salah satu siswa yang dipilih. Setelah siswa membaca wacana tersebut siswa menuliskan rumusan masalah atau suatu permasalahan. Pada tahap ini terlihat aktivitas siswa yang paling menonojol yaitu kerjasama dan mengamati, sedangkan untuk aktivitas siswa bertanya terdapat 1 siswa dan mengemukakan pendapat terdapat 3 siswa. Berikut beberapa rumusan masalah yang telah dituliskan siswa dan tutor sebaya ialah apakah yang dimaksud garam menghidrolisis? dan garam apa saja yang dapat menghidrolisis?. Rumusan masalah siswa yang dibuat telah sesuai dengan materi pembelajaran yang akan dipelajarai atau harapan guru. Pada tahap ini aktivitas siswa yang dilatihkan ialah mengemukakan ide atau pendapat.

Kemudian guru meminta siswa dan tutor sebaya untuk memperhatikan tahap selanjutnya yaitu membuat hipotesis dimana pembuatan hipotesis yang sesuai dengan materi yang akan dicapai.

Pada tahap ini terdapat 4 siswa yang mengemukakan hipotesis sesuai dengan hasil kelompok dan tidak terdapat siswa yang bertanya mengenai pembuatan hipotesis. Aktivitas lainnya yang terllihat yaitu mengamati dan kerjasama. Berikut merupakan beberapa hipotesis yang telah dibuat oleh siswa dan tutor sebaya ialah garam yang dapat mengalami hidrolisis adalah garam yang dapat memecah molekul air. Rumusan hipotesis yang dibuat siswa masih kurang tepat dengan materi pembelajaran yang akan dipelajari atau yang guru inginkan. Hipotesis yang guru inginkan ialah garam menghidrolisis adalah garam yang dapat memecah molekul air dan garam yang dapat mengalami hidrolisis ialah garam yang anion atau kationnya dapat memecah molekul air dan komponennya berasal dari asam atau basa yang bersifat lemah.

Untuk mengetahui apakah hipotesis yang dibuat sesuai dengan teori yang akan dipelajari maka dikerjakan pertanyaan-pertanyaan pada tahap pengumpulan data. Peran tutor sebaya sangat penting karena mereka yang membimbing teman sekelompok untuk dapat mengerjakan pertanyaan. Pada awal pertanyaan siswa dan tutor sebaya menghitung jumlah molekul yang terdapat dalam masing-masing larutan garam yang tersedia dalam LKS melalui gambar submikroskopis dan menuliskannya dalam tabel yang telah disediakan. Setelah siswa dan tutor sebaya menuliskan jumlah molekul pada tabel di LKS siswa dan tutor sebaya menceklis pada tabel apakah larutan tersebut kation maupun anionnya yang dapat memecah air (terlihat dari berkurang/ bertambahnya molekul di dalam larutan). Setelah siswa dan tutor sebaya selesai mengumpulkan data melalui pertanyaan-pertanyaan maka guru menunjuk perwakilan kelompok secara satu persatu untuk membacakan hasil dari kation maupun anion yang terpecah maupun tidak memecah air. Pada tahap ini terdapat 3 siswa yang bertanya dan 1 siswa yang mengemukakan 
pendapatnya, sedangkan banyak siswa terlihat mengamati dan bekerjasama dalam kelompoknya masing-masing.

Sebelum menemukan suatu konsep yang berkaitan dengan materi sebelumnya siswa dan tutor sebaya harus menganalisis data yang telah didapatkan dengan mengerjakan pertanyaan-pertanyaan yang ada pada LKS 2. Guru memberikan waktu untuk mengerjakan pertanyaanpertanyaan tersebut. Pada tahap ini peran tutor sebaya sangat penting dalam memberikan penjelasan kepada anggota kelompoknya. Dengan arahan dari pertanyaan LKS siswa dipastikan dapat membangun konsep mengenai konsep hisrolisis. Pada tahap ini terdapat 7 siswa yang bertanya dan 2 siswa yang mengemukakan pendapatnya, sedangkan banyak siswa terlihat mengamati dan bekerjasama dalam kelompoknya masing-masing. Hal ini terjadi karena pada materi kedua cendrung lebih susah dimengerti daripada pertemuan pertama.

Setelah siswa dapat menemukan konsep materi yang telah mereka pelajari, maka siswa dapat menyimpulkan konsep materi yang mereka telah pelajari. Pada tahap tersebut guru akan menunjuk 3 anak secara acak untuk menyimpulkan konsep materi yang telah mereka dapatkan (kecuali tutor sebaya). Pada tahap ini siswa sangat antusias dalam mengemukakan ide atau pendapat mereka. Pada pertemuan kedua, ratarata persentase aktivitas siswa dan keterlaksanaan model PLGI di kelas eksperimen semakin membaik. Hal ini didukung dari nilai rata-rata persentase aktivitas siswa sebesar 54,41 yang berkriteria sedang dan juga pelaksanaan model PLGI yang diimplementasikan guru dengan rata- rata persentase sebesar 82,54 yang berkriteria sangat tinggi. Guru sudah membimbing siswa dalam mengorientasi masalah di LKS, membuat hipotesis berdasarkan rumusan masalah yang telah dibuat siswa, mengumpulkan data berdasarkan gambar submikroskopis garam di dalam air, menganalisis data berdasarkan data yang diperoleh dan membuat kesimpulan berdasarkan pembelajaran yang telah dilakukan. Terjadi peningkatan dari pertemuan pertama sampai pertemuan kedua.

Pada kelas kontrol aktivitas siswa mengalami penurunan dari 43,56 menjadi 32,20. Faktor penyebab penurunan aktivitas siswa karena pada saat pembelajaran siswa hanya memperhatikan dan tidak bertanya ataupun mengungkapkan pendapatnya serta kerjasamanya pun kurang.

Pada pertemuan minggu ketiga tahapan pembelajaran PLGI dalam pembelajaran sama dengan pada pertemuan minggu kedua, hanya berbeda pada materi yang akan dicapai yaitu penentuan $\mathrm{pH}$. Tahapan dalam LKS model PLGI adalah yang pertama orientasi masalah. Sebelumnya pada LKS telah diberikan suatu wacana dimana di dalam wacana tersebut terdapat tabel data sifat kimia beberapa larutan garam berisi nilai $\mathrm{Ka}, \mathrm{Kb}, \mathrm{Kw}$, dan pH. Pada tahap ini siswa dan tutor sebaya tidak hanya dituntut untuk mengamati saja melainkan juga mengidentifikasi sifat kimia. Setelah siswa dan tutor sebaya mengamati dan memerhatikan dengan seksama wacana tersebut siswa menuliskan rumusan masalah atau suatu permasalahan berdasarkan dari wacana tersebut. Pada tahap ini aktivitas yang banyak terlihat yaitu mengamati dan kerjasama sedangkan untuk bertanya terdapat 2 siswa dan 
mengemukakkan pendapat yaitu 3 siswa. Berikut beberapa rumusan masalah yang telah dituliskan siswa dan tutor sebaya ialah bagaimana cara menghitung $\mathrm{pH}$ larutan garam?. Rumusan masalah siswa yang dibuat siswa sudah sesuai dengan yang diinginkan oleh guru yaitu bagaimana cara menghitung $\mathrm{pH}$ larutan garam? Pada tahap ini yang terlihat yaitu bertanya.

Kemudian guru meminta siswa dan tutor sebaya untuk memperhatikan tahap selanjutnya yaitu membuat hipotesis dimana pada tahapan ini pembuatan hipotesis sesuai dengan materi yang akan dicapai. Pada tahap ini tidak terdapat siswa yang bertanya dan terlihat 4 siswa yang mengemukakan pendapat, serta banyak siswa yang terlihat megamati dan bekerjasama dalam membuat hipotesis. Berikut merupakan beberapa hipotesis yang telah dibuat oleh siswa ialah $\mathrm{pH}$ larutan garam dapat dihitung menggunakanrumus berdasarkan nilai $\mathrm{Ka}$ dan $\mathrm{Kb}$. Hipotesis yang telah dibuat oleh siswa dan tutor sebaya sesuai dengan materi pembelajaran yang akan dipelajari atau sesuai dengan yang guru inginkan. Oleh karena siswa sudah terbiasa dalam melakukan model PLGI dengan tahap-tahap yang berada di dalam LKS.

Untuk mengetahui apakah hipotesis yang dibuat sesuai dengan teori yang akan dipelajari maka dikerjakan pertanyaan-pertanyaan pada tahap pengumpulan data. Sebelum menemukan suatu konsep yang berkaitan dengan materi sebelumnya siswa harus menganalisis data yang telah didapat dengan mengerjakan pertanyaan-pertanyaan yang ada pada LKS 3. Kemudian Guru memberikan waktu untuk mengerjakan pertanyaan-pertanyaan tersebut.

Pada LKS 3 tahap mengumpulkan data dan menganalisis data dilakukan sebanyak tiga kali. Pertama untuk mendapatkan rumus umum dengan komponennya berupa asam kuat dan basa lemah, kedua untuk mendapatkan rumus umum dengan komponennya berupa asam lemah dan basa kuat, dan ketiga untuk mendapatkan rumus umum dengan komponennya berupa asam lemah dan basa lemah. Pada tahap ini peran tutor sebaya sangat penting dalam memberikan penjelasan kepada anggota kelompoknya. Dengan pertanyaan LKS siswa dapat membangun konsep mengenai penentuan $\mathrm{pH}$. Pada tahap mengumpulkan data 2 siswa yang bertanya dan tidak ada siswa yang mengemukakan pendapatnya, sedangkan banyak siswa terlihat mengamati dan bekerjasama dalam kelompoknya masing-masing. Pada tahap menganalisis data terdapat 10 siswa yang bertanya dan 5 siswa yang mengemukakan pendapatnya, sedangkan banyak siswa terlihat mengamati dan bekerjasama dalam kelompoknya masing-masing. Banyaknya siswa yang bertanya maupun mengemukakan pendapat terjadi karena pada materi ini mengenai penurunan rumus untuk mendapatkan rumus umum yang sebelumnya belum pernah siswa lakukan.

Setelah siswa dapat menemukan konsep dari materi yang telah mereka pelajari, maka siswa dapat menyimpulkan konsep materi yang mereka telah pelajari (sebelumnya LKS sudah dikumpulkan kepada guru). Pada tahap tersebut guru akan menunjuk dua siswa secara acak untuk menyimpulkan konsep materi 
yang telah didapatkan (kecuali tutor sebaya).

Pada pertemuan minggu ketiga, dalam pembelajaran siswa sulit untuk konsentrasi dalam mengikuti pembelajaran. Hal ini dilihat dari materi penurunan rumus yang panjang dan hal ini menjadi hal baru dalam pembelajaran mereka serta kondisi kelas yang kurang kondusif pada kelas eksperimen berada pada 3 jam terakhir dan sebelumnya merupakan jam pelajaran olah raga. Walaupun materi pada LKS 3 terbilang cukup sulit tetapi tidak menyurutkan semangat mereka dalam belajar di dalam kelas. Hal ini didukung dari persentase aktivitas siswa sebesar 66,54 yang berkriteria tinggi dan juga pelaksanaan model PLGI yang diimplementasikan guru dengan presentase sebesar 83,44 yang berkriteria sangat tinggi. Guru sudah membimbing siswa dalam mengorientasi masalah di LKS, membuat hipotesis berdasarkan rumusan masalah yang telah dibuat siswa, mengumpulkan data berdasarkan reaksi ionisasi larutan garam, menganalisis data berdasarkan data yang diperoleh dan membuat kesimpulan berdasarkan pembelajaran yang telah dilakukan. Terjadi peningkatan dari pertemuan pertama sampai pertemuan keitga.

Pada kelas kontrol diperoleh persentase aktivitas siswa sebesar 34,47. Nilai rata-rata aktivitas siswa mengalami penurunan pada bagian bertanya sebesar 3 siswa dan bagian mengungkapkan ide/pendapat sebesar 2 siswa. Namun pada bagian mengamati sebesar 30 siswa dan kerjasama sebesar 12 siswa mengalami peningkatan, hal ini dikarenakan siswa lebih memperhatikan dan lebih bekerjasama saat mengerjakan soal yang berupa perhitungan. Tetapi nilai rata-rata aktivitas siswa kelas eksperimen lebih besar daripada kelas kontrol. Jadi dapat disimpulkan model pembelajaran di kelas eksperimen dapat meningkatkan penguasaan konsep siswa dibandingkan pada kelas kontrol pada materi garam menghidrolisis.

\section{SIMPULAN}

Berdasarkan hasil penelitian, analisis, dan pembahasan dapat disimpulkan bahwa model pembelajaran PLGI efektif dalam membangun konsep siswa ditunjukkan terdapat perbedaan yang signifikan antara rata-rata n-gain penguasaan konsep siswa pada kelas eksperimen yang menggunakan model PLGI dengan penguasaan konsep siswa kelas kontrol yang menggunakan model konvensional, dan juga didukung dengan data aktivitas siswa, dan data keterlaksanaan model PLGI.

\section{DAFTAR RUJUKAN}

Abdurrohim. (2016). Pengembangan Lembar Kegiatan Siswa (LKS) Berbasis Inkuiri Terbimbing Pada Materi Hidrolisis Garam. (Skripsi). Jakarta: Universitas Islam Negeri Syarif Hidayatullah. Anggoro, B. S. (2016). Meningkatkan Kemampuan Generalisasi Matematis Melalui Discovery Learning dan Model Pembelajaran Peer Led Guided Inquiry. (Skripsi). Lampung: IAIN Raden Intan.

Dewi, S.W. (2010). Pembelajaran Peer-Led Guided Inquiry pada Materi Redoks dalam Meningkatkan Penguasaan Konsep dan Keterampilan 
Berpikir Kritis Siswa SMA, (Tesis). Bandung: UPI Bandung.

Fadiawati, N. \& Syamsuri, M. M. F. (2016). Merancang Pembelajaran Kimia di Sekolah Berbasis Riset Pengembangan. Lampung: Media Akademi.

Gulo. (2010). Metodologi Penelitian. Jakarta: Grasindo.

Hermansyah, G., \& Herayanti, L. (2015). Pengaruh Penggunaan Laboratorium Virtual Terhadap Penguasaan Konsep Dan Kemampuan Berpikir Kreatif Siswa Pada Materi Getaran Dan Gelombang. Jurnal Pendidikan Fisika dan Teknologi. 1(2): 97102.

Iqbal, Z. Rudibyani, R.B., \& Efkar, T. (2018). Penerapan Model Problem Solving dalam Menigkatkan Penguasaan Konsep Asam Basa Arrhenius. Jurnal Pendidikan Kimia Unila, 7 (1): 50-62.

Kulatunga, U., Richard S. M. \& Jennifer E. L. (2013). Argumentation and Participation Patterns in General Chemistry Peer-Led Sessions. Journal Of Research In Science Teaching. 50 (10): 1207-1231.

Moseley. (2005). Framework of Thinking a Handbook for Teaching and Learning. Chambrige. Chambrige: University Press.

Nadiah, L., Mahdian, M., \& Hamid, A. (2017). Pengaruh Model Pembelajaran PLGI Terhadap Literasi Sains dan Hasil Belajar Siswa Pada Materi Hidrolisis Garam Siswa Kelas XI PMIPA SMAN 3 Banjarmasin. Journal of chemistry and education. 1(1): 73-85. Banjarmasin: Universitas Lambung Mangkurat.
Nuraeni, N. (2010). Efektivitas Penerapan Model Pembelajaran Generatif untuk Meningkatkan Pemahaman Siswa Dalam Mata Pelajaran Teknologi Informasi dan Komunikasi.(Skripsi). Bandung: UPI Bandung.

Purwanto. (2013). Evaluasi Hasil Belajar. Yogyakarta: Pustaka Pelajar.

Prasinta, J. D. (2018). Efektivitas Model Pembelajaran Adi Dalam Meningkatkan Penguasaan Konsep Siswa Pada Materi Zat Aditif dan Adiktif Berdasarkan Kemampuan Akademik.(Skripsi). Bandar Lampung: Universitas Lampung.

Rahmah, E., Rosilawati, I., \& Efkar, T. (2014). Model PLGI Materi Larutan Elektrolit Non-Elektrolit Dalam Meningkatkan Keterampilan Menyimpulkan Dan Mengkomunikasikan. (Skripsi). Bandar Lampung: Universitas Lampung.

Saumi, M., Sanjaya, \& Anom. (2014). Peningkatan Hasil Belajar Kimia Melalui Peran Tutor Sebaya Siswa Kelas X.A SMA. Jurnal Penelitian Pendidikan Kimia. 1(1):43-50.

Saputra, Z. A. H., Yuanita, L., \& Ibrahim, M. (2016). Pengembangan Perangkat Pembelajaran Kimia Model Inkuiri untuk Meningkatkan Penguasaan Konsep dan Melatih Keterampilan Berpikir Kritis Siswa SMA. Jurnal Pendidikan Sains. 6(1): 1218-1223.

Sari, I. N. (2018). Pengaruh Model Pembelajaran SiMaYang Dalam Meningkatkan Kemampuan Literasi Kimia Pada Materi Asam Basa. (Skripsi). Bandar Lampung: Universitas Lampung. 
Schraw, Gregory, \& Robinson, D. H. (2011). The Development of Higher Order Thinking Skill (HOT) Instrument Assessment in Physics Study. Assessment of Higher Order Thinking Skill. 22(1):26-32

Suyanti. (2016). Hubungan Antara Efikasi Diri Dan Kemampuan Metakognisi Dengan Penguaaan Konsep Kimia Siswa Melalui Model Simayang Tipe II. (Skripsi). Bandar Lampung: Universitas Lampung.

Rusmansyah. (2002). Penerapan Metode Latihan Berstruktur dalam Meningkatkan Pemahaman Siswa Terhadap Persamaan Reaksi Kimia. Jurnal
Pendidikan dan Kebudayaan. 35(8): 105-125.

Trianto. (2009). Mendesain Model Pembelajaran Inovatif-Progresif. Jakarta: Kencana.

Wasonowati, R. R.T., Redjeki, T., \& Ariani, S. R. D. (2014). Penerapan Model Problem Based Learning (PBL) Pada Pembelajaran Hukum - Hukum Dasar Kimia Ditinjau Dari Aktivitas Dan Hasil Belajar Siswa Kelas X IPA SMA Negeri 2 Surakarta Tahun Pelajaran 2013/2014. Jurnal Pendidikan UNS. 3(3): 66-75.

Wiseman, G. (2002). Nutrition and Health. Taylor and Francis, London. 